\title{
PENGARUH KOMUNIKASI ANTARA ATASAN - BAWAHAN TERHADAP MOTIVASI KERJA PEGAWAI BADAN LINGKUNGAN HIDUP KABUPATEN TEBO
}

\author{
Zike Martha, Diego, Ria Edlina \\ Universitas Dharma Andalas Padang \\ zikemartha17@gmail.com
}

Diajukan: 03-11-2017; Direview: 08-11-2017; Diterima: 11-12-2017;

\begin{abstract}
Communication is a basic human activity. It can not be denied that communication is very important for human beings, as well as in an organization. Communication within the organization are downward communication and upward communication which mean from the leaders to the subordinates and from subordinates leader in reciprocity. The role of all elements within the organization has a great influence in the process of communication within the organization. This research is a quantitative explanatory using survey method. The population of this study are employees in the Tebo District Environment, they are about 250 people, and using a simple random sampling. Based on the results of statistical tests of hypotheses - research hypothesis obtained significant results. The results shows that the communications of superiors - subordinates have a positive influence on employee work motivation Environment Agency Tebo District both variables have a strong relationship.
\end{abstract}

Keywords: Communication Between Superiors - Subordinates, Motivation Work.

\begin{abstract}
Abstrak
Komunikasi didalam organisasi adalah komunikasi internal yang mengalir secara vertikal yakni komunikasi dari atas kebawah (downward communication) dan dari bawah keatas (upward communication) dari pimpinan kebawahan dan dari bawahan ke pimpinan secara timbal balik (two way communication. Rumusan masalah penelitian bagaimana pengaruh komunikasi antar atasan-bawahan terhadap motivasi kerja pegawai pada Badan Lingkungan Hidup Kabupaten Tebo, sedangkan tujuan penelitian untuk mengetahui ada tidaknya pengaruh komunikasi atasan-bawahan terhadap motivasi kerja pegawai pada Badan Lingkungan Hidup Kabupaten Tebo. Penelitian ini bersifat kuantitatif eksplantif dengan menggunakan metode survey. Populasi dari penelitian ini adalah karyawan di lingkungan Badan Lingkungan Hidup Kabupaten Tebo sebanyak 250 orang. Rancangan sampling yang digunakan adalah simple random sampling. Untuk mengetahui pengaruh komunikasi atasan bawahan dilakukan analisis dengan menggunakan regresi linier sederhana dengan menggunakan ó sebesar 5\%. Berdasarkan hasil pengujian statistik terhadap hipotesis - hipotesis penelitian diperoleh hasil yang signifikan. Artinya bahwa komunikasi atasan - bawahan mempunyai pengaruh positif terhadap motivasi kerja pegawai Badan Lingkungan Hidup Kabupaten Tebo kedua variable mempunyai hubungan yang kuat.
\end{abstract}

Kata kunci : Komunikasi Antara Atasan-Bawahan, Motivasi Kerja.

\section{PENDAHULUAN}

$\mathrm{K}$ omunikasi merupakan proses penyampaian informasi dari satu pihak kepada pihak lain untuk mendapatkan saling pengertian. Komunikasi merupakan aktivitas dasar manusia sehingga manusia dapat saling berhubungan satu dengan lainnya baik dalam kehidupan sehari-hari maupun bermasyarakat atau dimana saja manusia berada. Tidak ada manusia yang tidak akan terlibat dalam komunikasi.Tidak dapat dipungkiri bahwa komunikasi sangatlah penting bagi manusia, begitu halnya didalam suatu organisasi. 
S.G Rogelberg (2009) mengatakan komunikasi mempunyai peranan penting khususnya didalam organisasi yaitu: "Dengan adanya komunikasi yang baik di suatu organisasi, maka organisasi tersebut akan berjalan dengan lancar dan berhasil begitupun sebaliknya, kurangnya atau tidak adanya komunikasi, organisasi dapat macet atau berantakan. Namun semua itu dapat terjadi didasari oleh bagaimana proses komunikasi dan juga sistem komunikasi yang ada didalam organisasi tersebut. Sudah berjalan baik atau belumkah proses komunikasi disana.

Komunikasi manusia adalah suatu proses melalui mana individu dalam hubungannya, dalam kelompok, dalam organisasi dan dalam masyarakat menciptakan, mengirimkan, dan menggunakan informasi untuk mengkoordinasi lingkungannya dan orang lain. Artinya bahwa komunikasi merupakan suatu proses aktivitas yang mempunyai beberapa tahap yang terpisah satu sama lain tetapi berhubungan. Didalam komunikasi adanya suatu proses penyampaian dan penerimaan informasi dari satu pihak kepada pihak lain untuk mendapatkan saling pengertian (Sundstrom, 2000:120). Karena begitu pentingnya komunikasi didalam organisasi, maka perlu bagi pimpinan/pihak manajemen didalam suatu organisasi harus mempunyai kemampuan dan keterampilan didalam berkomunikasi. Dan kemampuan berkomunikasi tersebut berlaku bagi semua pimpinan tanpa terkecuali baik itu jenis organisasi, aliran komunikasi dan juga kedudukan dari para pimpinan tersebut apapun statusnya (Parker, 2008:33)

Untuk komunikasi, jika dilihat dari line secara vertikal, terdapat beberapa jabatan dengan satu orang atasan artinya bahwa didalam melakukan kegiatan kerja seorang atasan akan dibantu dan juga adanya pelimpahan sebagian hak atau wewenang dari pejabat pimpinan kepada pejabat yang ada dibawahnya untuk mengambil tindakan yang dianggap paling tepat sehingga tugas dan tanggungjawabnya itu dapat dilaksanakan dengan sebaik-baiknya. Seperti halnya seorang Deputi pada organisasi dimana penulis meneliti, selain memberikan intruksi kerja berupa perintah atau arahan namun disamping itu juga meminta masukan atau petunjuk dari para bawahannya didalam menangani permasalahan yang ada serta didalam menanggapi sesuatu hal, baik internal maupun eksternal.Artinya bahwa walaupun Deputi sebagai salah satu pejabat Eselon I yang posisinya berada dibawah Menteri, namun tidak menunjukkan bahwa para pejabat ini adalah orang yang sangat berkuasa dan juga perkasa yang tidak mungkin tidak membutuhkan dan memerlukan bantuan orang lain didalam melakukan segala tugas dan kewajibannya untuk bekerjasama dan juga berkoordinasi dengan para bawahannya. Semua itu berlaku juga untuk para pejabat lainnya. Oleh sebab itu peranan komunikasi antara atasan dan bawahan disini sangat penting didalam mendukung segala kegiatan kerja agar berjalan dengan baik dan benar sehingga mencapai keberhasilan yang sesuai dengan tujuan bersama. Dan untuk komunikasi secara horizontal, linenya mengalir secara horizontal atau kesamping dan sejajar, dan biasanya yang dilakukan sebagai bentuk dari koordinasi antara pejabat atau pimpinan yang setingkat dalam suatu organisasi akan kebijakankebijakan didalam organisasi. Disini komunikasi harus berjalan dengan baik, karena dengan adanya komunikasi yang baik, maka kerjasama diantara mereka akan berjalan dengan baik pula sehingga tugas pokok dan intruksi kerja masing - masing pejabat akan berjalan dengan lancar sesuai dengan aturan yang ada, selain itu juga hal tersebut akan mempengaruhi organisasi.

Badan Lingkungan Hidup Kabupaten Tebo merupakan salah satu perusahaan pemerintahan atau disebut juga perusahaan birokrasi. Dan banyak orang berpendapat bahwa didalam organisasi pemerintah/ birokrasi kedudukan suatu jabatan sangatlah penting, karena didalam saluran-saluran birokrasi telah tersusun secara hirarki sesuai dengan struktur organisasi.Sehingga hubungan dan juga komunikasi yang terjadi tidak berjalan dengan bebas karena adanya batasan-batasan yang mungkin secara tidak langsung dan disadari sudah melekat pada diri pejabat-pejabat di dalam organisasi tersebut sehingga dalam tingkah laku, sikap dan perbuatannya bersifat formal. Begitupun didalam melakukan segala urusan kurang fleksibel (kurang luwes) atau kaku karena setiap urusan 
terlalu terikat oleh suatu ketentuan, peraturan, prosedur yang pada umumnya terlalu berbelitbelit dan terkadang sering terjadinya hambatan dan juga kemacetan (Soehoet, 2002). Pada dasarnya semua itu bukan disebabkan karena birokrasi tetapi disebabkan birokrasi yang tidak baik, sehingga hal tersebut menimbulkan pandangan dan pengertian yang keliru tentang birokrasi. Perlu diketahui bahwa setiap organisasi baik itu birokrasi maupun yang bukan birokrasi pasti mempunyai aturan atau prosedure atau ketentuan yang berlaku didalam menjalankan segala aktifitas kerja organisasi, dengan maksud agar semua aktifitas tersebut dapat berjalan dengan baik dan lancar sesuai dengan maksud dan tujuan. (Kohn and Wolfe, 2001:26).

Berdasarkan latar belakang masalah diatas, maka rumusan masalah dalam penelitian ini adalah: Apakah Komunikasi antara atasan-bawahan akan mempengaruhi motivasi kerja pegawai pada Badan Lingkungan Hidup Kabupaten Tebo? Tujuan penelitian dalam penulisan ini adalah untuk mengetahui: Ada tidaknya pengaruh komunikasi atasan-bawahan terhadap motivasi kerja pegawai pada Badan Lingkungan Hidup Kabupaten Tebo?

\section{LITERATUR DAN METODOLOGI}

Dengan berkomunikasi manusia dapat saling berhubungan satu sama lainnya didalam kehidupan. Pentingnya komunikasi bagi manusia tidaklah dapat dipungkiri begitupun juga halnya bagi suatu organisasi. "Komunikasi dalam Organisasi adalah suatu proses penyampaian informasi, ide-ide, diantara para anggota organisasi secara timbalbalik dalam rangka mencapai tujuan yang telah ditetapkan". Artinya bahwa didalam komunikasi, antara anggota organisasi adanya interaksi satu dengan lainnya saling memberi dan menerima informasi, ide-ide, gagasan dan sebagainya sehingga memperoleh suatu kesepahaman atau kesamaan persepsi dan pandangan atau suara yang bulat didalam mencapai suatu tujuan bersama (Rowe and Mason, 2007: 1-17).

Komunikasi didalam organisasi terdiri dari dua bagian berdasarkan dimana khalayak berada yaitu komunikasi internal dan komunikasi eksternal. Namun yang akan lebih dibahas dalam penelitian ini adalah komunikasi internal. Komunikasi internal adalah komunikasi antara manajer atau atasan dengan komunikan yang berada di organisasi yakni para pegawai secara timbal balik. Komunikasi internal terbagi menjadi tiga kegiatan yakni komunikasi vertikal, komunikasi horisontal dan komunikasi diagonal. Komunikasi vertikal, yakni komunikasi dari atas ke bawah (downward communication) dan dari bawah keatas (upward communication) adalah komunikasi dari pimpinan ke bawahan dan dari bawahan ke pimpinan secara timbal balik (two-way communication). Didalam proses komunikasi vertikal tersebut pimpinan atau atasan memberikan instruksi, petunjuk, pengarahan, informasi, penjelasan dan lain-lain kepada bawahannya, sedangkan bawahan memberikan laporan, gagasan, saran dan sebagainya kepada pimpinan.

Komunikasi organisasi adalah suatu sistem yang saling tergantung yang mencakup komunikasi internal dan komunikasi eksternal. Komunikasi internal disini adalah komunikasi dalam organisasi itu sendiri seperti komunikasi dari atasan kepada bawahan, komunikasi dari bawahan kepada atasan, komunikasi sesama karyawan yang sama tingkatnya. Sedang komunikasi eksternal adalah komunikasi yang dilakukan organisasi terhadap lingkungan luarnya, seperti hubungan dengan masyarakat umum dan pihak-pihak terkait (stakeholders). Didalam komunikasi dua arah tersebut dalam organisasi sangat penting sekali karena jika didalam komunikasi proses komunikasinya hanya satu arah saja dari pimpinan ke bawahan, maka proses kegiatan kerja didalam organisasi besar kemungkinan tidak berjalan sebagaimana yang diharapkan. Atasan atau pimpinan perlu mengetahui laporan, tanggapan, gagasan, atau saran dari para pegawai sebagai petunjuk efektif tidaknya dan efisien tidaknya kebijaksanaan yang telah dilakukan (Arni, 2009). Komunikasi horisontal adalah komunikasi secara mendatar artinya komunikasi yang terjadi antara para bawahan, dan biasanya komunikasi tersebut terjadi dalam suasana yang tidak formal seperti suasana santai ketika para pegawai sedang istirahat atau ketika dalam acara-acara kekeluargaan dan sebagainya. Komunikasi diagonal atau disebut juga komunikasi silang (cross communication) 
adalah komunikasi yang terjadi didalam organisasi antara satu orang dengan orang lain yang masingmasing berbeda dalam kedudukan dan bagianya. Seperti contoh antara seorang supir dengan kepala Biro Umum. Komunikasi yang terjadi antara mereka pada umumnya tidak menampakkan kekakuan karena bersifat formal seperti pada komunikasi vertikal dan juga tidak menunjukkan keakraban sebagaimana halnya pada komunikasi horisontal. Komunikasi diagonal tersebut biasanya terjadi pada suasana tidak formal seperti pada saat rekreasi, pesta perkawinan dan sebagainya.

Komunikasi organisasi akan berjalan dengan baik dan lancar serta mencapai hasil yang maksimal, maka perlu didukung oleh adanya interaksi atau suatu hubungan yang baik dan komunikasi yang baik pula antara atasan dengan bawahan atau sebaliknya, antara para pimpinan yang selevel atau setingkat, antar karyawan dengan karyawan lainnya dan juga seluruh elemen-elemen terkait lainnya didalam maupun diluar organisasi (Jalalluddin Rachmat, 2004). Komunikasi dapat diklasifikasikan menjadi dua yaitu komunikasi langsung (direct communication) dan komunikasi tidak langsung (indirect communication). Komunikasi yang terjadi dimana penulis meneliti bersifat formal dan juga non formal. Untuk komunikasi secara formal didalam pemberian informasi atau didalam penyampaian pesan memanfaatkan saluran-saluran formal yang ada didalam organisasi. Saluran formal tersebut adalah saluran birokrasi yang telah tersusun secara hirarkis sesuai dengan struktur organisasi. Didalam komunikasi formal tersebut dibedakan menjadi dua sifat yaitu tertulis dan tidak langsung, serta lisan dan langsung. Untuk komunikasi yang formal dan tertulis dan tidak langsung adalah komunikasi yang dalam penyampaian informasi atau pesannya secara tertulis dan tidak langsung karena menggunakan media tertentu seperti surat dan memo, hal tersebut dapat dilihat seperti surat masuk dari bidang atau instansi lain tidak dapat langsung diterima oleh orang yang dituju misalnya Deputi, maka surat tersebut harus melewati jalur lain dahulu seperti ke Tata Usaha kemudian dicatat di agenda surat masuk dan dibuatkan disposisi baru kemudian disampaikan kepada Deputi, dan dari Deputi di disposisikan kepada bawahan yang sesuai dengan bidangnya atau tupoksinya (Ruslan, 2003).

Untuk komunikasi formal yang bersifat lisan, dapat dilihat atau biasanya terjadi ketika adanya rapat-rapat internal seperti Rapat Pimpinan yang dihadiri oleh Bapak Menteri dan para pejabat Eselon I dan II dan juga rapat MPR/DPR dengan Komisi VII dan sebagainya.Didalam komunikasi formal tersebut selain membicarakan masalah kegiatan-kegiatan dan program kerja juga menginformasikan akan kebijakan, aturan dan ketentuan-ketentuan yang berlaku didalam organisasi. Selain itu organisasi juga harus mengkomunikasikan permasalahan atau isuisu dan juga krisis yang sedang terjadi didalam organisasi. Dengan tujuan agar semua karyawan siapapun, apapun kedudukannya, bagaimanapun ia, harus mengikuti dan mengetahui akan situasi dan kondisi yang sedang dialami perusahaan (Hayati, 2005:25). Penyampaian pesan untuk komunikasi formal memang lebih banyak tertulis daripada lisan dengan maksud agar lebih mudah didalam penanganannya dan pendokumentasian serta untuk memudahkan pencarian jika sewaktu-waktu dokumen tersebut diperlukan untuk dipelajari kembali.Sedangkan untuk komunikasi yang non formal dan langsung biasanya terjadi ketika adanya rapat-rapat internal yang tidak bersifat formal seperti rapat Asdep, rapat staf, dan juga ketika adanya acara-acara yang bersifat kekeluargaan seperti family gathering, arisan, dharmawanita, hari ulang tahun nasional organisasi dan situasi dan kondisi tertentu (Liliweri, 2007:17).

Untuk aliran komunikasi didalam organisasi, mengalir secara vertikal yang terdiri atas downward communication dan upward communication artinya bahwa komunikasi yang terjadi antara atasan dengan bawahan mengalir secara dua arah (two way communication) secara timbal balik, karena didalam komunikasi tersebut seorang pimpinan tidak hanya mengintruksikan kerja atau perintah kepada bawahannya namun disini pimpinan juga meminta saran dan juga pendapat atau ide-ide didalam melaksanakan tugas dan kewajibannya di dalam organisasi. Selain itu juga bawahan kepada atasannya akan memberikan 
laporan kerja, memberikan masukan, pendapat dan menyampaikan rencana dan program kerja dan lain sebagainya yang menjadi tugas dan kewajibannya sesuai dengan TUPOKSI yang diberikan atasan. Komunikasi dua arah secara timbal balik tersebut dalam organisasi penting sekali karena jika hanya satu arah saja dari pimpinan kepada bawahan, roda organisasi tidak akan berjalan dengan baik. Pimpinan perlu mengetahui laporan, 13 tanggapan, atau saran para karyawan sehingga suatu keputusan atau kebijaksanaan dapat diambil dalam rangka mencapai tujuan yang telah ditetapkan (Liliweri, 2004:34).

Dengan begitu antara pimpinan dan bawahan memiliki suatu hubungan yang baik, saling ketergantungan satu sama lain, dan peran serta dari bawahan atau para pegawai adalah penting bagi pimpinan didalam menjalankan roda organisasi. Dengan begitu kegiatan kerja, kerjasama dan juga koordinasi didalam organisasi lancar, baik dan juga efektif karena komunikasi antara atasan dan bawahan tersebut berjalan dengan baik pula. Namun perlu diingat bahwa karena komunikasi menyangkut masalah hubungan manusia dengan manusia, maka suksesnya komunikasi ditentukan oleh orang-orang yang terlibat didalamkomunikasi tersebut (Yuyun Wirasmita, 2003). Komunikasi dikatakan efektif apabila dalam suatu proses komunikasi itu pesan yang disampaikan seorang komunikator dapat diterima dan dimengerti oleh komunikan persis seperti yang dikehendaki oleh komunikator. Artinya bahwa pesan-pesan yang disampaikan oleh komunikator dapat diterima dan dimengerti dengan baik oleh komunikan, dan dalam mengartikan atau memaknai akan isi pesan tersebut, sesuai dengan maksud dan tujuan dari si komunikator. Sehingga dengan demikian proses komunikasi yang terjadi antara komunikator dengan komunikan berjalan dengan efektif dan lancar karena adanya satu kepahaman diantaranya.

\section{TEMUAN DAN DISKUSI}

Dalam penelitian ini, untuk proses komunikasi yang cocok dan sesuai dengan proses komunikasi yang terjadi di Badan Lingkungan Hidup Kabupaten Tebo adalah model komunikasi dari Seiler. Secara sederhana proses komunikasi yang efektif antara atasan dan bawahan atau sebaliknya dapat dilihat pada model komunikasi oleh seiler. yang digambarkan pada gambar 1 .

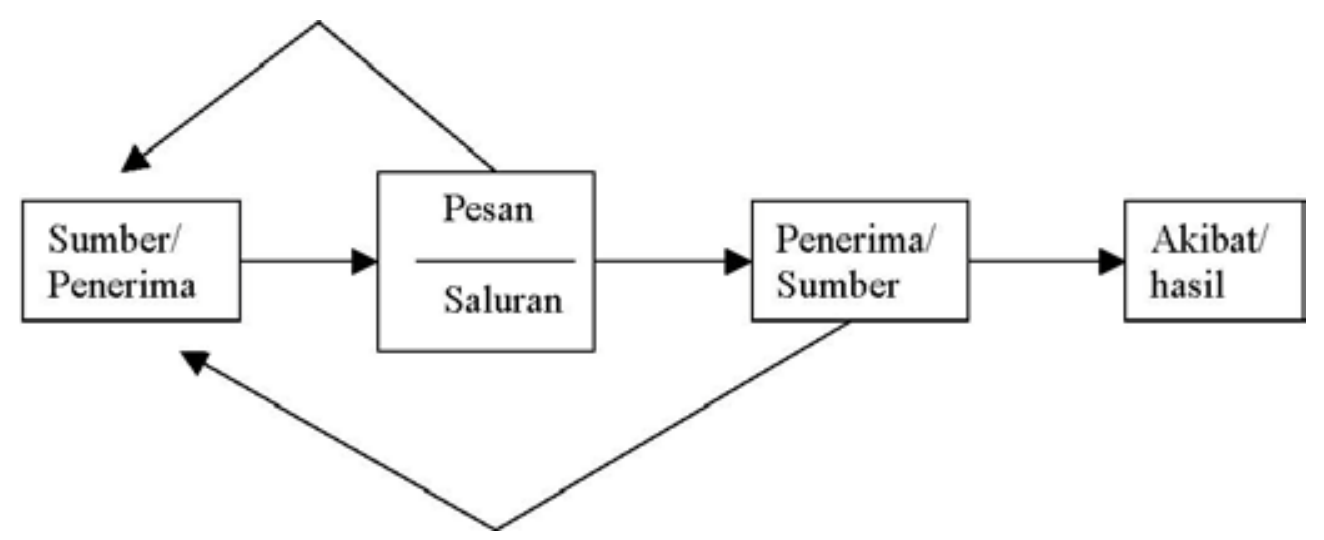

Gambar1. Proses Komunikasi Umpan Balik

Pihak sumber membentuk pesan (encoder) dan menyampaikannya melalui suatu saluran tertentu (misalnya melalui surat, telepon atau kalau bentuk komunikasinya secara langsung/tatap muka, maka yang menjadi salurannya adalah gelombang udara). Pihak penerima kemudian mengartikan dan menginterpretasikan pesan tersebut. Apabila ia (penerima)punya tanggapanmakaiakemudianakan membentuk pesan dan menyampaikannya kembali kepada si sumber. Tanggapan yang disampaikan penerima pesan kepada sumber tersebut disebut sebagai umpan balik. Pihak sumber kemudian akan mengartikan dan menginterpretasikan tanggapan tadi, dan kembali ia akan melakukan pembentukan dan penyampaian pesan baru. Proses ini akan terus berlanjut secara sirkuler, dimana kedudukan sebagai sumber (komunikator) dan penerima (komunikan) berlaku secara bergantian. 
Komunikasi adalah: "Proses komunikasi yang mengacu pada tindakan, oleh satu orang atau lebih yang mengirim dan menerima pesan yang terdistorsi oleh gangguan (noise), terjadi dalam konteks tertentu, mempunyai pengaruh tertentu dan ada kesempatan untuk melakukan umpan balik." Dalam proses komunikasi, seringkali terjadi faktor umpan balik kurang menjadi perhatian, padahal dalam kenyataannya faktor umpan baliklah ynag menjadi motor penggerak komunikasi sehingga proses komunikasi dapat berjalan secara efektif. Terkadang pesan yang dikirim oleh sumber pesan (encoder) tidak memperoleh umpan balik yang memadai seperti yang diharapkan oleh pemberi pesan. Penyebab utama dari kegagalan proses umpan balik ini adalah disebabkan oleh adanya kegagalan untuk mengurangi gangguan-gangguan (noise) yang timbul dari proses komunikasi.

Gangguan-gangguan yang terjadi didalam komunikasi pada dasarnya tidaklah dapat dihindarkan, tapi dapat diupayakan untuk dikurangi, yaitu melalui proses pembelajaran sehingga kompetensi komunikasi (kemampuan untuk berkomunikasi secara efektif) semakin dapat ditingkatkan. Kompetensi tersebut haruslah dimiliki oleh setiap individu dalam konteks interaksi dengan pihak lain. Walaupun terkadang didalam komunikasi sering terjadi mis atau bias yang menyebabkan komunikasi tidak dapat menerima dan memahami pesan itu sesuai yang dikehendaki oleh komunikator, dan komunikasi tersebut dianggap gagal. Untuk itu didalam berkomunikasi perlu memperhatikan beberapa hal yang penting agar kegagalan didalam komunikasi dapat dihindari. (Ruslan, 2003: 38). Kegagalan tersebut disebabkan oleh adanya gangguan (noise)/ hambatan didalam proses komunikasi, dan faktor penghambat didalam komunikasi adalah sebagai berikut: Hambatan Sosiologi yaitu hambatan yang disebabkan oleh adanya perbedaan status, idiologi, agama, tingkat pendidikan, status ekonomi. Hambatan ini lebih nampak pada pelaksanaan komunikasi formal dikarenakan adanya perbedaan kedudukan dan jabatan. Hambatan Psikologis yakni hambatan komunikasi yang disebabkan oleh situasi psikologi yang tidak mendukung diantaranya.
Hambatan Semantis ialah hambatan komunikasi yang disebabkan oleh latar belakang bahasa yang berbeda dalam memaknai suatu pesan. Contohnya adalah "jangan" untuk bahasa Indonesia artinya larangan sedangkan untuk bahasa orang Jawa berarti sayur. Gangguan - gangguan yang terjadi didalam komunikasi pada dasarnya tidaklah dapat dihindarkan, tapi dapat diupayakan untuk dikurangi, yaitu melalui proses pembelajaran sehingga kompetensi komunikasi (kemampuan untuk berkomunikasi secara efektif) semakin dapat ditingkatkan. Kompetensi tersebut haruslah dimiliki oleh setiap individu dalam konteks interaksi dengan pihak lain. Artinya bahwa komunikasi merupakan hal yang mudah dipelajari, semakin seringnya orang berkomunikasi dan berinteraksi dengan orang lain, maka semakin mudah mengetahui dan memahami bagaimana harus berbicara sesuai dengan situasi dan kondisi yang sedang berlangsung yaitu berkomunikasi secara efektif, disitulah terjadinya proses pembelajaran didalam berkomunikasi. (Susanto, 2008:18).

Berdasarkan aliran humanistik, efektifitas komunikasi ditentukan oleh keterbukaan(openess), empati (empathy), dukungan (supportiveness), rasa positif (positiveness) dan kesamaan (equality) sehingga tercapai interaksi yang memuaskan. Keterbukaan (openess) merujuk pada tiga aspek komunikasi interpersonal. Pertama, komunikator harus selalu terbuka/jujur terhadap lawan bicaranya. Kedua, ada niat baik dari komunikator untuk bereaksi secara jujur terhadap stimuli yang datang. Ketiga, komunikator harus selalu menyadari perasaan dan pikiran terbuka yang diekspresikan berasal dari dalam hatinya sendiri, sehingga bertanggungjawab terhadapnya. Empati adalah sikap turut merasakan perasaan orang lain. Suasana mendukung (supportiveness) harus dilakukan dengan cara memberikan sifat openminded, perhatian terhadap orang lain dan tegar dalam menghadapi sikap oposisi dari orang lain. Sikap positif (positiveness) mengacu pada sedikitnya dua aspek komunikasi antar pribadi yaitu komunikasi antarpribadi terbina jika orang memiliki sikap positif terhadap diri mereka sendiri, perasaan positif untuk situasi komunikasi 
pada umumnya sangat penting untuk interaksi yang efektif. Kesamaan (equality) terjadi bila kedua belah pihak dianggap dan menganggap sama-sama berharga, mengkontribusi komunikasi yang seimbang dan saling menghormati.(Liliweri, 2007:37).

Menurut pendapat Greenberg dan Baron "Motivasi adalah suatu proses yang mendorong, mengarahkan dan memelihara perilaku manusia ke arah pencapaian suatu tujuan". Motivasi merupakan masalah kompleks dalam organisasi yang pada dasarnya bersifat subyektif sehingga ada seseorang yang memiliki motivasi rendah sementara yang lainnya memiliki motivasi yang tinggi. Didalam perusahaan atau organisasi, tumbuh dan berkembangnya motivasi dalam diri karyawan menjadi faktor yang penting untuk diperhatikan apabila perusahaan/organisasi menginginkan peningkatan, baik itu produktivitas usaha ataupun kemajuan-kemajuan lainnya bagi perusahaan. Menurut Siagian (2001:11) pengertian motivasi adalah daya pendorong yang mengakibatkan seseorang anggota perkantoran mau dan rela untuk mengerahkan kemampuan dalam bentuk keahlian dan keterampilan, tenaga dan waktunya untuk menyelenggarakan berbagai kegiatan yang menjadi tanggung-jawab dalam menunaikan kewajibannya dalam rangka pencapaian tujuan dan berbagai sasaran perkantoran yang telah ditentukan sebelumnya. Untuk itu motivasi didalam organisasi mempunyai peranan yang sangat penting disamping komunikasi, karena dengan adanya motivasi mampu meningkatkan kinerja organisasi dan juga karyawan.

Didalam penelitian ini penulis menggunakan teori motivasi yang dikemukakan oleh Herzberg yang mana menurut penulis teori tersebut sesuai dengan situasi dan kondisi yang ada di organisasi dimana penulis meneliti. Menurut Herzberg ada dua faktor pendorong didalam motivasi yang pertama adalah dissatiffiers factor yaitu faktor yang membuat pegawai merasa tidak puas dan yang kedua adalah satisfiers factor yaitu faktor yang membuat pegawai merasa puas. Untuk dissatiffiers factor atau disebut juga faktor extrinsic yang berarti bersumber dari luar diri seseorang misalnya dari organisasi, faktor extrinsic tersebut terdiri dari serangkaian kondisi kerja yang meliputi : " Gaji atau upah, Keamanan kerja, Kondisi Kerja, Status, Kebijaksanaan Perusahaan, Mutu dan Teknik Pengawasan, Interaksi antar personal ". Apabila faktor-faktor tersebut telah ada didalam organisasi maka tidak perlu adanya motivasi, namun sebaliknya jika tidak ada maka akan menyebabkan rasa tidak puas dikalangan para pegawai. Sedangkan untuk satisfiers factor atau disebut juga intrinsic yang berarti bersumber dari dalam diri seseorang yang terdiri dari serangkaian kondisi yang meliputi beberapa faktor sebagai berikut : "Pengakuan (recognition), Tanggung Jawab (responsibility), Prestasi (achievement), Pekerjaan itu sendiri (the work itself), Adanya kemungkinan untuk berkembang (the possibility of growth), Kemajuan (advancement)" Serangkaian kondisi tersebut apabila terpenuhi akan meningkatkan motivasi kerja para pegawai, hal tersebut disebabkan karena rangkaian diatas melukiskan hubungan seseorang dengan apa yang dikerjakannya yakni kandungan pekerjaan atas tugasnya. Faktor-faktor tersebut diatas dinamakan juga motivators.

Perlu diingat bahwa ketika seseorang mulai memasuki dunia kerja, maka orang tersebut akan membawa karakteristik pribadinya kedalam lingkungan kerja. Namun didalam lingkup organisasi perilaku seseorang akan berbeda dibanding saat orang tersebut seorang diri, hal tersebut disebabkan karena didalam organisasi terdapat suatu kontrol formal dan informal yang berdampak pada pembentukan segala perilaku didalam organisasi, termasuk dalam pembuatan kebijakan, prosedur kerja, pertauran-peraturan didalam organisasi, deskripsi kerja dan intruksi kerja, dimana semua hal tersebut sangat terkait dengan system komunikasi didalam organisasi. Bila pegawai merasa cocok atau senang dengan system komunikasi yang ada di organisasi, maka berpengaruh pula terhadap kepuasan kerjanya, apabila pegawai puas, maka kinerjanya umumnya meningkat. Selain itu juga hubungan antara atasan dengan bawahan berlangsung dengan baik maka akan tercipta suasana kerja yang menyenangkan, yang mana hal tersebut akan membawa dampak pada kepuasan kerja. Oleh sebab itu Komunikasi internal antara atasan dengan bawahan didalam 
organisasi diharapkan dapat menjadi pengaruh eksternal, artinya bahwa dengan komunikasi yang terjalin antara atasan dengan bawahan yang berjalan dengan baik, terbuka, dan dua arah serta dengan adanya saling pengertian dan pemahaman akan mampu mendorong motivasi yang positif pada seluruh pegawai.

Motivasi pegawai pada dasarnya merupakan sikap mental individu atau kelompok yang terdapat dalam organisasi atau perusahaan yang mencerminkan kegairahan dalam melaksanakan pekerjaan dan mendorong karyawan untuk bekerja lebih baik dan produktif. Motivasi karyawan merupakan hal yang penting dan timbul antara lain dengan diberikan dukungan oleh pimpinan. Komunikasi yang efektif antara pimpinan dan pegawai sangat penting bagi motivasi pegawai. Sikap pimpinan, umpan balik dan mampu mendengarkan sangat diperlukan untuk komunikasi yang baik. Selain memberikan perintah dan juga petunjuk seorangt pimpinan hendaknya bersedia bernegosiasi dengan pegawainya sehingga para pegawai lebih mudah menerima dan mengerti pesan-pesan yang disampaikan pimpinan kepadanya dengan cara mendiskusikannya dari pada hanya sekedar perintah. Didalam berdiskusi tersebut dapat dilakukan dengan beberapa cara seperti halnya Rapat Asdep, Rapat Staf dan sebagainya yang dimana dalam rapat tersebut adanya interaksi secara langsung antara atasan dan juga bawahan, dan cara tersebut merupakan cara yang lebih efisien dan efektif. Dan perlu diingat bahwa komunikasi merupakan salah satu faktor yang dapat mempengaruhi motivasi.

Untuk memotivasi bawahan, para pimpinan dapat melakukan beberapa cara memotivasi dalam berbagai variasi bentuk seperti: "Memberi Teladan, Memberi dorongan, Memberi pujian, Mengakui kemajuan yang dicapai karyawan, dan sebagainya. Cara-cara yang ditempuh atau teknik yang dilakukan oleh pimpinan untuk memotivasi karyawannya agar lebih termotivasi bagi yang sudah mempunyai motivasi dan membangkitkan serta menumbuhkan semangat dan juga dorongan bagi para pegawai yang memang kurang atau tidak ada semangat kerja sehingga timbul gairah kerjanya kembali, hal tersebut tergantung bagaimana pimpinan melakukannya. Karena tidak dapat dipungkiri bahwa motivasi kerja ada dikarenakan adanya suatu dorongan baik yang berasal dari dalam diri seseorang maupun juga dari luar (pihak luar seperti pimpinan ataupun organisasi). Oleh sebab itu penting bagi seorang pemimpin dan juga organisasi untuk mampu berkomunikasi dengan baik sehingga tercipta komunikasi dua arah yang harmonis antara atasan dengan bawahan. Ketidak seimbangan arus komunikasi dikhawatirkan akan membawa dampak pada munculnya tindakantindakan yang mengindikasikan ketidak puasan kerja seperti timbulnya keluhan-keluhan, desasdesus, absensi yang tinggi bahkan sampai mogok kerja dan sebagainya. Dengan memahami dan mengerti akan semua keinginan dan kebutuhan dari para bawah/pegawainya merupakan salah satu cara guna menghindari adanya hal-hal yang tidak diinginkan tersebut, yang akan berdampak buruk bagi organisasi. Karena perlu diingat bahwa tidak akan ada organisasi tanpa adanya karyawan atau pekerja dan tidak ada pekerjaan tanpa adanya organisasi. Dapat disimpulkan bahwa antara pihak organisasi dengan para pekerja mempunyai hubungan yang sangat erat sekali diantara keduanya saling berhubungan dan juga ketergantungan, menjadi satu kestuan yang utuh dan tidak dapat dipisahkan.

Berdasarkan pendahuluan yang telah dikemukakan mengenai komunikasi atasanbawahan dapat mempengaruhi motivasi pegawai dalam penelitian ini, maka dapat diajukan beberapa hipotesa sebagai jawaban sementara dari permasalahan yang ada bahwa ada hubungan dan juga pengaruh antara komunikasi atasanbawahan terhadap motivasi kerja yaitu dengan: ada pengaruh yang signifikan antara komunikasi atasan-bawahan terhadap motivasi kerja pegawai Badan Lingkungan Hidup Kabupaten Tebo. Tipe penelitian yang dipakai adalah kuantitatif eksplanatif. Penelitian kuantitatif adalah suatu tipe penelitian yang menekankan pada fenomenafenomena objektif yang dikaji secara kuantitatif. Maksimalisasi objektifitas desain penelitian ini dilakukan dengan menggunakan angka-angka, pengolahan statistik, struktur dan percobaan yang terkontrol dengan memberikan eksplanasi 
(kejelasan) tentang hubungan antara peristiwa dengan makna. Eksplanatif adalah suatu penelitian yang ditujukan untuk memberikan penjelasan tentang hubungan antar fenomena atau variable. Penelitian eksplanatif mencoba mencari kejelasan hubungan antar hal tersebut. Hubungan tersebut bisa berbentuk hubungan korelasi atau saling berhubungan atau hubungan sebab akibat satu variable dengan variable lainnya.

Metode yang digunakan dalam penelitian ini adalah metode survei. Metode survei ini digunakan untuk mengumpulkan data atau informasi tentang populasi yang besar dengan menggunakan sample yang relative kecil. Didalam metode penelitian, populasi adalah serumpun atau sekelompok objek yang menjadi sasaran penelitian. Oleh karenanya populasi penelitian merupakan keseluruhan (universum) dari objek penelitian yang dapat berupa manusia, hewan, tumbuh-tumbuhan, udara, gejala, nilai, peristiwa, sikap hidup, dan sebagainya sehingga objek-objek ini dapat menjadi sumber data penelitian. Populasi dalam penelitian ini adalah para pegawai tetap yang berada dilingkungan Badan Lingkungan Hidup Kabupaten Tebo dengan tidak membedakan usia, jenis kelamin, jabatan, maupun golongan, dengan jumlah pegawai 250 orang.

Sampel adalah wakil semua unit strata dan sebagainya yang ada didalam populasi. Untuk jumlah sampel yang akan diambil dari populasi tersebut perlu dilakukan pendekatan statistik, dan sampel tersebut diambil secara acak sederhana (simple random sampling) dari populasi dengan menggunakan rumus: $\mathrm{n}=$ ukuran sampel, $\mathrm{N}=$ ukuran populasi, $\mathrm{e}=$ persentase ketidaktelitian karena kesalahan pengambilan sampel yang masih dapat diinginkan sekitar 2\%.

Maka yang akan digunakan sebagai sample dalam penelitian ini adalah 63 orang dari 250 pegawai. Jumlah sample tersebut diambil dari 5 bidang pada Badan Lingkungan Hidup Kabupaten Tebo, yang masing-masing bidang akan diambil sebagai sample adalah 13 orang. Dapat dilihat pada Tabel 1 .

Komunikasi Atasan-Bawahan adalah Suatu proses komunikasi yang terjadi antara atasan dengan bawahan yang dilakukan baik secara formal maupun nonformal didalam organisasi. Motivasi Kerja adalah dorongan atau semangat kerja dengan menggunakan segala kemampuan yang dimiliki guna memperoleh hasil yang sebaikbaiknya dengan dilakukan secara kesadaran diri dan penuh rasa tanggung jawab.

Tabel 1. Unit Kerja Responden Sumber : Kuesioner No. h

\begin{tabular}{ll}
\hline \multicolumn{1}{c}{ Unit Kerja } & F \\
\hline Pusarpedal & 14 \\
\hline Pusdiklat & 13 \\
\hline Datin & 13 \\
\hline Stanteksih & 13 \\
\hline Indal & 10 \\
\hline Total & $\mathbf{6 3}$ \\
\hline
\end{tabular}

Secara operasional komunikasi atasan-bawahan yang terjadi didalam organisasi baik secara formal maupun nonformal, dapat diukur dengan beberapa indikator keberhasilan yaitu: Keterbukaan (openenss) merujuk pada tiga aspek komunikasi interpersonal. komunikator harus selalu terbuka/ jujur terhadap lawan bicaranya, ada niat baik dari komunikator untuk bereaksi secara jujur terhadap stimuli yang dating, komunikator harus selalu menyadari perasaan dan pikiran terbuka yang diekspresikan berasal dari dalam hatinya sendiri, sehingga bertanggungjawab terhadapnya, Empati adalah sikap turut merasakan perasaan orang lain. Suasana mendukung (supportiveness) harus dilakukan dengan cara memberikan sifat open-minded, perhatian terhadap orang lain dan tegar dalam menghadapi sikap oposisi dari orang lain. Sikap positif (positiveness) mengacu pada sedikitnya dua aspek komunikasi antar pribadi yaitu: Komunikasi antarpribadi terbina jika orang memiliki sikap positif terhadap diri mereka sendiri. Perasaan positif untuk situasi komunikasi pada umumnya sangat penting untuk interaksi yang efektif. Kesamaan (equality) terjadi bila kedua belah pihak dianggap dan menganggap sama-sama berharga, mengkontribusi komunikasi yang seimbang dan saling menghormati. Teknik pengumpulan data-data untuk survai adalah teknik pengumpulan data yang terdiri dari data primer dan data sekunder. 
Dalam penelitian ini untuk menganalisis data, maka akan dilakukan mekanisme pengambilan data dengan menggunakan Kuesioner yaitu suatu teknik atau cara pengumpula data secara tidak langsung (peneliti tidak langsung bertanya jawab dengan responden). Kuesioner tersebut telah dibuat daftar kuesioner yaitu serangkaian pertanyaan yang diajukan kepada responden guna mengumpulkan informasi dari responden mengenai objek yang sedang diteliti, baik berupa pendapat, tanggapan, ataupun tentang dirinya sendiri. Tujuannya adalah untuk memberikan kebebasan kepada responden untuk menjawab atau merespon pertanyaan sesuai dengan persepsinya. Dalam kuesioner, pertanyaan yang digunakan adalah pertanyaan-pertanyaan terbuka, yang berisi pertanyaan-pertanyaan dan pernyataan pokok yang bisa dijawab atau direspon oleh responden secara bebas. Tidak ada anak pertanyaan ataupun rincian yang memberikan arah dalam pemberian jawaban atau respon. Guna memperoleh data dan informasi yang bermutu dan memperoleh keberhasilan dalam penelitian maka perlu dibuat daftar kuesioner (daftar pertanyaan) yaitu serangkaian pertanyaan yang diajukan kepada responden untuk mengumpulkan informasi dari responden mengenai objek yang sedang diteliti baik berupa pendapat, tanggapan, ataupun tentang dirinya sendiri. Alternatif persepsi atau tanggapan, dalam hal ini penulis menggunakan skala likert dengan skor 1 sampai 5 yaitu $1=$ Sangat Tidak Setuju (STS), 2 = Tidak Setuju (TS), 3 = Raguragu $(\mathrm{R}), 4=$ Setuju $(\mathrm{S})$, dan $5=$ Sangat Setuju (SS).

Studi Kepustakaan merupakan pencarian data dan bahan-bahan sebagai data pendukung yang diperoleh penulis dengan membaca dan mempelajari buku-buku referensi dan tulisantulisan lainnya yang berhubungan dengan permasalahan. Tujuan dilakukan uji validitas adalah untuk mengukur apakah data yang diberikan pada kuesioner dapat dipercaya atau tidak serta dapat mewakili apa yang hendak diteliti. Dalam penelitian kali ini untuk menguji validitas data, maka penulis menggunakan SPSS versi 11,5 dengan hasil sebagai berikut: Uji reliabilitas adalah tingkat kestabilan suatu alat pengukur dalam mengukur suatu gejala atau kejadian. Semakin tinggi reliabilitas suatu alat pengukur, semakin stabil pula alat pengukur tersebut untuk mengukur suatu gejala dan sebaliknya jika reliabilitas tersebut rendah maka alat tersebut tidak stabil dalam mengukur suatu gejala. Untuk mengetahui pengaruh komunikasi atasan bawahan dilakukan analisis dengan menggunakan regresi linier sederhana. Analisis regresi linier sederhana adalah sebuah analisis statistik untuk melihat hubungan fungsional antara satu variable bebas (komunikasi atasan-bawahan) dan satu variable terikat (motivasi kerja). Hubungan fungsional tersebut dapat ditulis dengan persamaan sebagai berikut: $Y$ $=\mathrm{a}+\mathrm{bX}$ dimana langkah-langkah pengujiannya adalah menentukan formulasi Ho dan $\mathrm{Ha}$ dalam kalimat Ho: Tidak ada pengaruh antara variable $\mathrm{X}$ dan variable $\mathrm{Y}, \mathrm{Ha}$ : Ada pengaruh antara variable $\mathrm{X}$ dengan variable $\mathrm{Y}$. Dalam bentuk statistik Ha : $\beta$ $\neq 0$, Ho $: \beta=0$. Uji Statistik $\mathrm{T}=1 \mathrm{lbS}-\beta$, dimana $\mathrm{b} 1=$ koefisien regresi $(\mathrm{a}, \mathrm{b}), \mathrm{S}=$ Simpangan baku untuk koefisien regresi. Kriteria pengujian Ho diterima apabila $\mathrm{t}$ hitung $<\mathrm{t}$ tabel, Ha ditolak apabila $t$ hitung $>\mathrm{t}$ tabel.

\section{SIMPULAN}

Penelitian ini bertujuan untuk mengetahui Pengaruh Komunikasi Atasan-Bawahan terhadap Motivasi Kerja Pegawai Badan Lingkungan Hidup Kabupaten Tebo. Ada tidaknya pengaruh Komunikasi Atasan-Bawahan terhadap Motivasi Kerja Pegawai dapat dilihat sebagai berikut: Dipenelitian ini memperlihatkan komunikasi atasan-bawahan terhadap motivasi kerja pegawai Kementerian Lingkungan Hidup dengan menggunakan metode regresi linier sederhana memberikan hasil pengujian yang signifikan pada taraf signifikansi sebesar 5\%. Dengan demikian dapat disimpulkan bahwa komunikasi atasanbawahan mempunyai pengaruh yang signifikan terhadap motivasi kerja pegawai Kementerian Lingkungan Hidup.

Dengan adanya penelitian ini, diharapkan dapat memberikan manfaat bagi pengembangan ilmu komunikasi, khususnya tentang pentingnya komunikasi Atasan-Bawahan terhadap Motivasi Kerja Pegawai di Badan Lingkungan Hidup Kabupaten Tebo. Diharapkan dengan adanya 
penelitian ini dapat memberikan masukan, saran, dan referensi serta sebagai pedoman bagi perusahaan atau organisasi bahwa Komunikasi antara Atasan-Bawahan mampu mempengaruhi motivasi kerja para pegawai sehingga mampu memperoleh hasil yang optimal didalam mencapai keinginan dan tujuan bersama.

\section{DAFTAR PUSTAKA}

Arni Muhhamad. 2009. Komunikasi organisasi. Jakarta: PT. Bumi Aksara.

A.J Rowe dan R.O Mason. 2007. Guide to Understanding, Assesing and Improving Decision Making).

Hayati, Syaodih Nana. 2005. Metode Penelitian Pendidikan. Bandung: PT. Remaja Rosda Karya.

Liliweri, Alo. 2004. Komunikasi Antar Pribadi. Bandung: PT. Citra Aditya Bakti.

Liliweri, Alo. 2007.Perspektif Teoritis Komunikasi Antarpribadi. Bandung: PT. Citra Aditya Bakti.

Rachmat, Jalaluddin. 2004. Psikologi Komunikasi. Edisi Revisi. Bandung: PT. Remaja Rosdakarya.
R.L Kohn, D.M Wolfe, ed July 2001 “organizationa Stress:Studies in Role Conflict and AmbiQuty",

Rosady, Ruslan. 2003. Metode Penelitian Publik Relation dan Komunikasi. Jakarta: PT. Raja Grafindo Persada (Rajawali Pers).

Santoso, Priyo Budi. 2003. Birokrasi Pemerintah Orde Baru, Perspektif Kultural dan Struktural. Jakarta: PT.Rajawali Pers.

Siagian, Sondang P, Soehoet, Hoeta. 2001. Teori Komunikasi 2. Jakarta: Yayasan Kampus Tercinta IISIP.

Susanto Phil Astrid. 2008. Manajemen Publik Relation. Jakarta: PT. Raja Grafiindo Persada.

Sumber lain:

Journal of Applied Psyhology 77 ( Oktober 2009)

Parker G.M, 2008. "The New Competitive Business Strategy"

Rogelberg S.G, 2009, Ed Oktober 2009 "Journal of Applied Psyhology 77"

Sundstrom, Februari 2000 K.P "Work Teams 